\title{
Pengembangan Aplikasi Penerimaan Siswa Baru Berbasis Web Mobile SMA Negeri 1 Ulu Belu
}

\author{
Muhamad Muslihudin ${ }^{1}$, M.Arif Imamudin' ${ }^{2}$, \\ ${ }^{1,2}$ Prodi Sistem Informasi, STMIK Pringsewu, Lampung \\ Jl. Wisma Rini No.09 Pringsewu, Lampung, Indonesia \\ e-mail:*1'mmuslihudin415@gmail.com, ${ }^{2}$ m.arif.imamudin@gmail.com
}

\begin{abstract}
Acceptance of new students is one of the processes that exist in educational institutions such as schools. New admissions process (PSB) at SMAN 1 Ulu Belu who still use the conventional system, so that prospective students are sometimes difficult to obtain information on the registration process. The registration process also tends to be slow, because the data are not yet integrated and managed. This process also still us the archive in a physical form that is susceptible to damage or even disappear. In order to overcome the problems that occurred in the registration of new students at SMAN 1 Ulu Belu made designing and building applications Admission Information Systems Web-Based Mobile. The method used for the construction of information systems using modeling Entity Relationship Diagram. The result of the design and construction of this information system is the existence of a mobile web-based web that can provide easy access to information and registration processes so that the process of accepting new students becomes more effective and efficient.
\end{abstract}

Keywords: information systems, new admissions, WEB, Mobile.

\begin{abstract}
Abstrak
Penerimaan siswa baru merupakan salah satu proses yang ada di instansi pendidikan seperti sekolah. Proses penerimaan siswa baru (PSB) di SMAN 1 Ulu Belu yang masih mengunakan sistem konvensional, sehingga calon siswa terkadang kesulitan mendapatkan informasi untuk melakukan proses pendaftaran. Proses pendaftaran juga cenderung lambat, karena data belum terintegrasi dan terkelola dengan baik. Proses ini juga masih menggunakan arsip dalam bentuk fisik yang rentan mengalami kerusakan atau bahkan hilang. Untuk dapat mengatasi permasalahan yang terjadi pada pendaftaran siswa baru di SMAN 1 Ulu Belu dibuatlah perancangan dan pembangunan aplikasi Sistem Informasi Penerimaan Siswa Baru Berbasis Web Mobile. Metode yang digunakan untuk pembangunan sistem informasi menggunakan permodelan Entity Relationship Diagram. Hasil akhir dari perancangan dan pembangunan sistem informasi ini adalah adanya sebuah web berbasis web mobile yang dapat memberi kemudahan akses informasi dan proses pendaftaran sehingga proses penerimaan siswa baru menjadi lebih efektif dan efisisen.
\end{abstract}

Kata kunci: sistem informasi, penerimaan siswa baru, WEB, Mobile.

\section{PENDAHULUAN}

\subsection{Latar Belakang Masalah}

enurut data badan pusat statitik kabupaten Tanggamus 2015 menunjukkan bahwa jumlah sekolah yang ada di kabupaten Tanggamus ada 47 sekolah, dan data siswa yang ada di kabupaten Tanggamus ada 9.819 siswa. Sedangkan data sekolah SMA di kabupaten Tanggamus ada 26 sekolah, dan jumlah siswa SMA yang ada di Kabupaten Tanggamus ada 7.852 siswa. [1] Sekolah adalah tempat berkumpulnya semua orang untuk mendapatkan 
pengetahuan yang luas sesuai dengan aturan yang ditetapkan pemerintah dengan ketentuan SD 6 Tahun, SMP 3 Tahun, dan SMK 3 Tahun dan harapan pemerintah agar mampu menciptakan generasi penerus bangsa yang berkualitas yang mampu mewujudkan Indonesia yang maju.

Hasil penelitian yang dilakukan oleh Sugeng Santoso, et.all (2013). Hasil dari penelitian ini adalah tersedianya aplikasi penerimaan siswa baru. Dengan aplikasi ini calon siswa baru dapat mengisi form pendaftaran, melihat informasi berkaitan dengan pendaftaran secara mobile. Dan pihak sekolah mendapatkan kemudahan dalam mengelola data baik dari pengarsipan, melihat rekapitulasi data pendaftaran hingga menginformasikan jadwal serta hasil dari test calon siswa [2]. Sistem informasi berkembang dari sebatas pengolah data atau penyaji informasi menjadi mampu untuk menyediakan pilihan-pilihan sebagai pendukung dalam penerimaan siswa baru. Hasil penelitian yang dilakukan oleh Nur Heri Cahyana, et.all (2015). Sistem penerimaan seleksi berbasis Web dengan menggunakan pengembangan perangkat lunak sukensial linier (air terjun), yang memiiki beberapa tahapan, termasuk persyaratan perangkat lunak tahap analisis, tahap desain, tahap pembuatan kode, tahap pengujian dan tahap pemeliharaan, sehingga dihasilkan aplikasi memiiki keungguan dalam pengolahan data [3]. Penelitian yang dilakukan oleh Sri Hartati, et.all (2018) Kombinasi SMS Gateway pada sistem monitoring absensi di SMAN 2 Pringsewu memberikan dampak yang positif dan secara otomatis memberikan pemberitahuan kepada orang tua siswa tentang kehadiran siswa di sekolah [4]. Sistem informasi penerimaan siswa baru berbasis web mobile bertujuan untuk mempermudah proses penerimaan siswa baru.

Dalam penelitian sebelumnya Sistem Penerimaan Siswa Baru (PSB) bersifat manual menggunakan buku, sehingga proses laporannya berjalan lambat. Mulai dari pendataan siswa yang mendaftar, ujian seleksi, sampai pengumuman lulus dan tidak lulus ujian seleksi. Ketika laporan tersebut dibutuhkan kembali, maka pencarian laporan mengenai data hasil pendataan siswa yang mendaftar, sekolah harus mencari terlebih dahulu pada arsip. Pencarian laporan tersebut akan mengakibatkan keterlambatan dalam proses pemecahan masalah yang akan dilakukan terkait mengenai keingintahuan orang tua siswa atau keingintahuan Kepala Sekolah mengenai siswanya. Dalam penelitian ini berfungsi untuk mempermudah dan mempercepat dalam proses pendaftaran siswa baru, sehingga lebih efisien dan hasil dari seleksi dapat dilihat secara online, jadi siswa pendaftar tidak perlu melihat hasil seleksi ke sekolah. Penelitian yang dilakukan bertujuan bagaimana merancang dan membangun sistem informasi penerimaan siswa baru untuk membantu penyelesaian terhadap calon siswa baru di SMA Negeri 1 Ulu Belu Kabupaten Tanggamus yang tepat dan efisien.

\subsection{Rumusan Masalah}

Berdasarkan uraian latar belakang maka yang menjadi perumusan masalah yaitu, bagaimana menerapkan sistem informasi penerimaan siswa baru berbasis web mobile pada sistem penerimaan siswa baru

\section{LANDASAN TEORI}

\subsection{Konsep Sistem Informasi}

Sistem informasi menurut Burch dan Strater (1974) dalam Moekijat (2005), adalah kumpulan bagian-bagian yang formal dan sistematis yang melaksanakan operasi pengolahan data untuk memenuhi persyaratan pengolahan data yang legal dan transaksional, memberikan informasi kepada manajemen untuk mendukung kegiatan kegiatan perencanaan, pengendalian, dan pengambilan keputusan, serta memberikan bermacam-macam laporan seperti yang diperlukan pihak luar [5]. Susanto (2004) Sistem Informasi adalah kumpulan dari sub-sub sistem baik fisik maupun non fisik yang saling berhubungan satu sama lain dan bekerjasama 
secara harmonis untuk satu tujuan yaitu mengolah data menjadi informasi yang berarti dan berguna [6].

Sistem adalah bagaian-bagian yang saling berkaitan yang beroperasi bersama untuk mencapai beberapa sasaran untuk melakukan suatu kegiatan atau menyelesaikan suatu aturan tertentu didalam sistem juga terdapat beberapa unsur-unsur didalamnya yaitu seperti masukan (input), pengelolaan (processing), dan keluaran (output). Suatu sistem bertanggung jawab terhadap sebuah proses masukan sehingga menghasilkan sebuah keluaran [7]. Verdy Yasin (2007) menjelaskan Aplikasi adalah suatu subkelas perangkat lunak komputer yang memanfaatkan kemampuan komputer langsung untuk melakukan suatu tugas yang diinginkan pengguna [8].

\subsection{Karakteristik Sistem}

Menurut Jeperson Hutahaean (2014), Sebuah sistem memiliki karakteristik sistem yang dapat membedakan suatu sistem dengan sistem lainnya komponen sistem, batasan sistem (Boundary), lingkungan luar sistem (Environment), penghubung sistem (Interface), masukan sistem (Input), keluaran sistem (Output) [9].

\subsection{Definisi Sekolah}

Menurut Syamsu Yusuf (2001), sekolah adalah tempat peserta didik untuk dapat memperoleh pendidikan. Sekolah dapat diartikan sebagai sebuah lembaga tempat proses belajar mengajar pada sebuah sistem pendidikan yang diakui oleh negara. Meskipun demikian terdapat juga beberapa sistem pendidikan yang bertujuan layaknya seperti sekolah formal dengan bentuk yang berbeda seperti yang dikenal istilah home schooling, akan tetapi sekolah adalah sistem pendidikan yang paling terkenal bahkan ada disetiap negara [10].

\subsection{Definisi Siswa}

Undang-Undang Republik Indonesia Nomor 20 Tahun 2003 tentang Sistem Pendidikan Nasional, menjelaskan bahwa Siswa adalah Anggota masyarakat yang berusaha mengembangkan potensi diri melalui proses pembelajaran yang tersedia pada jalur, jenjang, dan jenis pendidikan tertentu. Siswa juga dapat diartikan sebagai orang yang dengan sengaja belajar di sekolah untuk mengembangkan potensi diri melalui proses pembelajaran pada suatu jalur pendidikan baik pendidikan formal (dari tingkat sekolah dasar, sekolah menengah pertama, dan sekolah menengah atas), maupun pendidikan nonformal [11].

\subsection{Website dan Web Mobile}

Website atau situs dapat diartikan sebagai kumpulan halaman halaman yang digunakan untuk menampilkan informasi, teks, gambar diam atau bergerak, animasi, suara, dan atau gabungan dari semuanya itu, baik yang bersifat statis maupun dinamis yang membentuk satu rangkaian bangunan yang saling berkait dimana masing masing dihubungkan dengan jaringan jaringan halaman (hyperlink) [12]. Budi Darytamo (2011), kata mobile mempunyai arti bergerak atau berpindah. Sehingga diperoleh pengertian bahwa aplikasi Web Mobile merupakan aplikasi yang dapat dijalankan dimanapun, bisa lewat android dan laptop [13].

\section{METODE PENELITIAN}

\subsection{Tahap Pengumpulan Data}

a. Metode Observasi

Pada tahap observasi ini peneliti melakukan suatu pengamatan secara langsung tentang keadaan SMA Negeri 1 Ulu Belu, yang kemudian dilanjutkan dengan proses perancangan web pendaftaran siswa baru yang dijadikan objek peneliti. Dari hasil observasi tersebut peneliti 
mencatat secara sistematis terhadap gejala-gejala yang berhubungan dengan masalah yang akan diteliti. Catatan yang diperoleh dari pengamatan ini adalah berupa data pendaftaran siswa baru yang prosesnya masih manual.

\section{b. Metode Interview}

Dalam tahap ini peneliti melakukan suatu pendekatan kepada guru khususnya kepala sekolah SMA Negeri 1 Ulu Belu tentang pendaftaran siswa baru berbasis web mobile yang dijadikan objek penelitian untuk memperoleh suatu data ataupun informasi yang dibutuhkan untuk membantu calon siswa dalam proses pendaftaran yang telah ditentukan yaitu dengan cara interview atau wawancara yang kemudian hasil yang diperoleh akan dibandingkan dengan proses pendaftaran siswa yang bersifat manual.

\section{c. Metode Kepustakaan}

Dalam tahap penelitian ini, penulis juga menggunakan metode kepustakaan atau studi pustaka yang berupa referensi dari jurnal-jurnal penelitian terdahulu. Dalam hal ini penulis mencari, mempelajari, dan merangkum berbagai macam pustaka ataupun referensi jurnal yang terkait dengan permasalahan penelitian.

\subsection{Metode Pengembangan Sistem Informasi}

Metodologi pengembangan sistem informasi berarti suatu metode yang digunakan untuk melakukan pengembangan sistem informasi berbasis komputer. Menurut Ladjamudin (2009), Metode System Development Life Cycle merupakan pengembangan yang berfungsi sebagai sebuah mekanisme untuk mengidentifikasikan perangkat lunak. Pengembangan sistem informasi yang berbasis komputer dapat merupakan tugas kompleks yang membutuhkan banyak sumber daya dan dapat memakan waktu untuk menyelesaikannya [14]. Pengembangan System Development Life Cycle dikerjakan secara berurut menurun dari perencanaan, analisis, desain, implementasi dan perawatan [15] [16]. Berikut gambar siklus hidup pengembangan sistem SDLC:

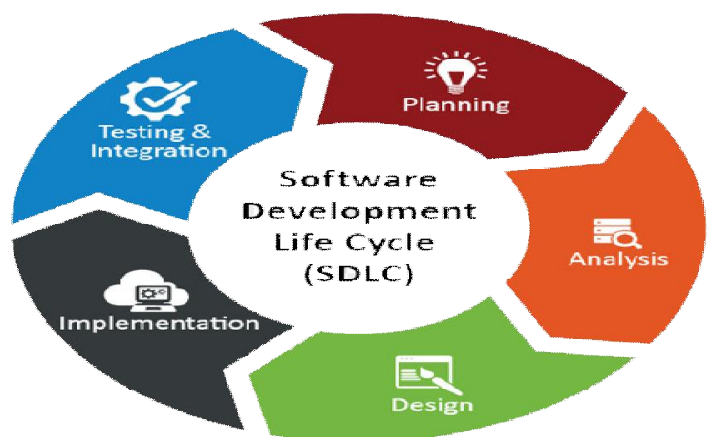

Gambar 1. Siklus SDLC

a. Perencanaan Sistem (System Planning)

Fase perencanaan adalah sebuah proses dasar untuk memahami mengapa sebuah sistem harus dibangun. Pada fase ini diperlukan analisa kelayakan dengan mencari data atau melakukan proses Information Ghatering kepada pengguna. Perencanaan untuk pengembangan sistem adalah dengan menggunakan bahasa pemograman HTML 5 dan dibantu dengan database MySQL.

b. Analisis Sistem (System Analyze)

Fase analisa adalah sebuah proses investigasi terhadap sistem yang sedang berjalan dengan tujuan untuk mendapatkan jawaban mengenai pengguna sistem, cara kerja sistem dan waktu penggunaan sistem. Dari proses analisa didapatkan beberapa masalah yaitu dalam 
penginputan data calon siswa baru terjadi kesalahan yang akan membuat dokumen atau laporan sulit ditemukan jika dibutuhkan. Dalam pembuatan laporan membutuhkan waktu yang lama dan tidak efisien.

c. Desain Sistem (Design System)

Tahap selanjutnya adalah desain sistem yang akan menggambarkan fungsional dari sistem yang akan dibangun secara keseluruhan. Sistem yang digunakan menggunakan aplikasi yang memakai bahasa pemograman HTML 5, dan menggunakan Database MySQL dan diagram yang digunakan dalam perancangan sistem adalah Usecase Diagram, dan Class Diagram.

d. Implementasi Sistem (Implementation)

Fase implementasi adalah proses pembangunan dan pengujian sistem, instalasi sistem, dan rencana dukungan sistem. Sistem yang telah dirancang, kemudian dicoding, diuji, dan diinstall. Sistem ini bisa dipakai di sekolah untuk mempermudah calon siswa baru dalam proses pendaftaran siswa baru dan melihat melihat informasi tentang penerimaan siswa baru.

e. Perawatan Sistem (Maintanance)

Merupakan tahap akhir dimana data dapat dipastikan secara sistematik sistem informasi dapat diperbaiki dan dikembangkan. Dalam perawatan sistem akan dilakukan proses pemantauan jalannya sistem baru ini pada SMA Negeri 1 Ulu Belu.

\section{PEMBAHASAN DAN PENGUJIAN}

\subsection{Perancangan Sistem Informasi}

Dalam perancangan sistem ini, penulis menggunakan beberapa alat bantu untuk menjelaskan proses pendataan yang dilakukan dalam data tersebut. Adapun tahap dalam proses tersebut adalah sebagai berikut:

Use Case Diagram

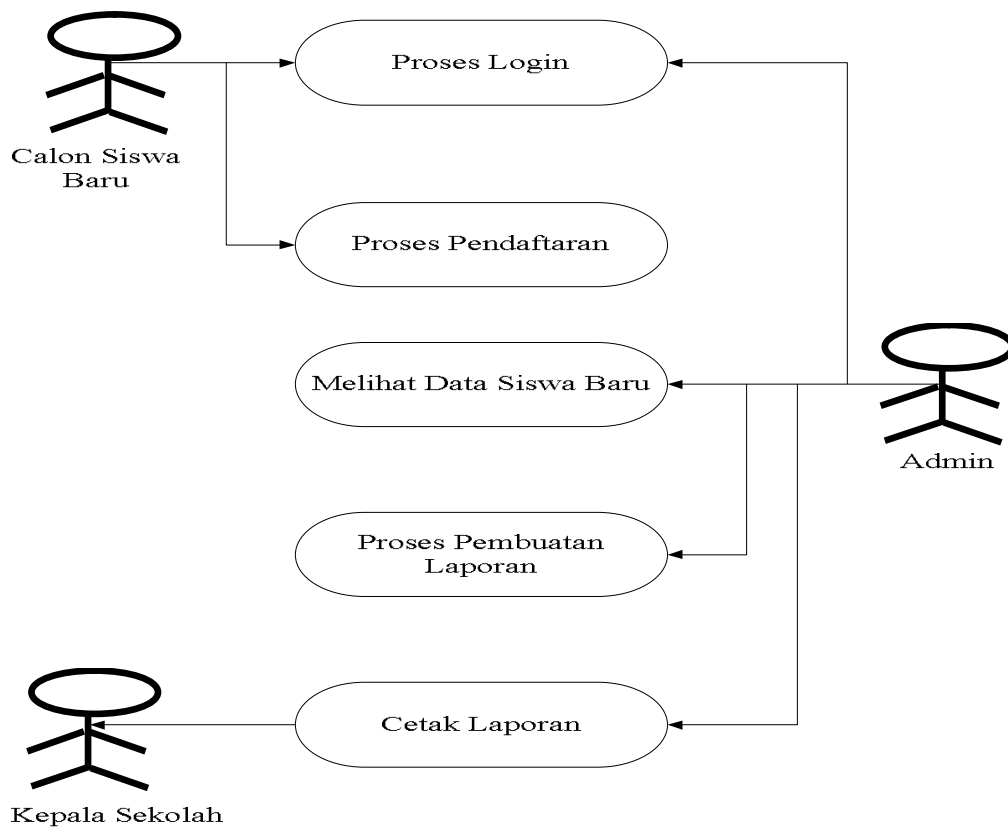

Gambar 2. Use Case Diagram Alur Sistem 


\section{Rancangan Database}

Alat permodelan yang digunakan untuk menggambarkan hubungan antara entitas, yang terjadi berisi komponen-komponen entitas, dan relation yang masing-masing dilengkapi dengan atribut-atribut yang mempresentasikan seluruh fakta dari sebagian dunia nyata. Berikut adalah Entity Relationship Diagram.

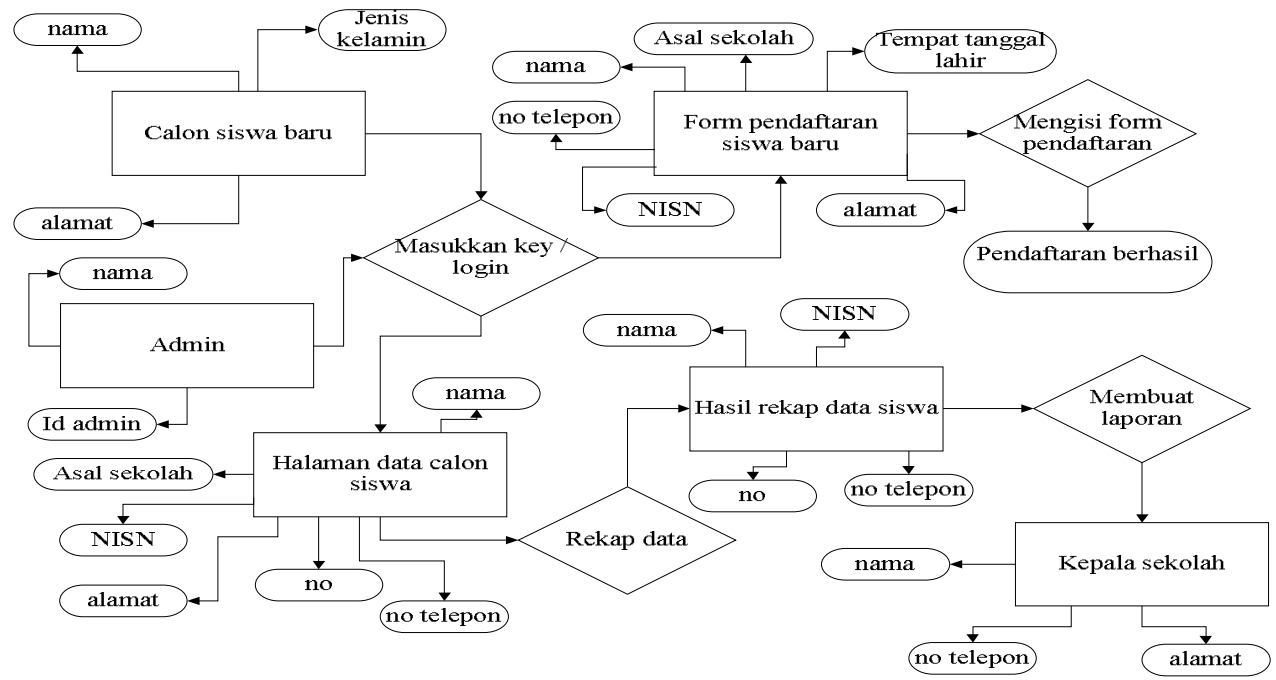

Gambar 3. Rancangan Database Pendaftaran Siswa Baru

Flowchart Alur Kerja Sistem

Flowchart (aliran kerja) atau aktivitas dari sebuah sistem dan user. Berikut ini adalah diagram dalam perancangan sistem informasi penerimaan siswa baru berbasis web mobile di SMAN 1 Ulu Belu.

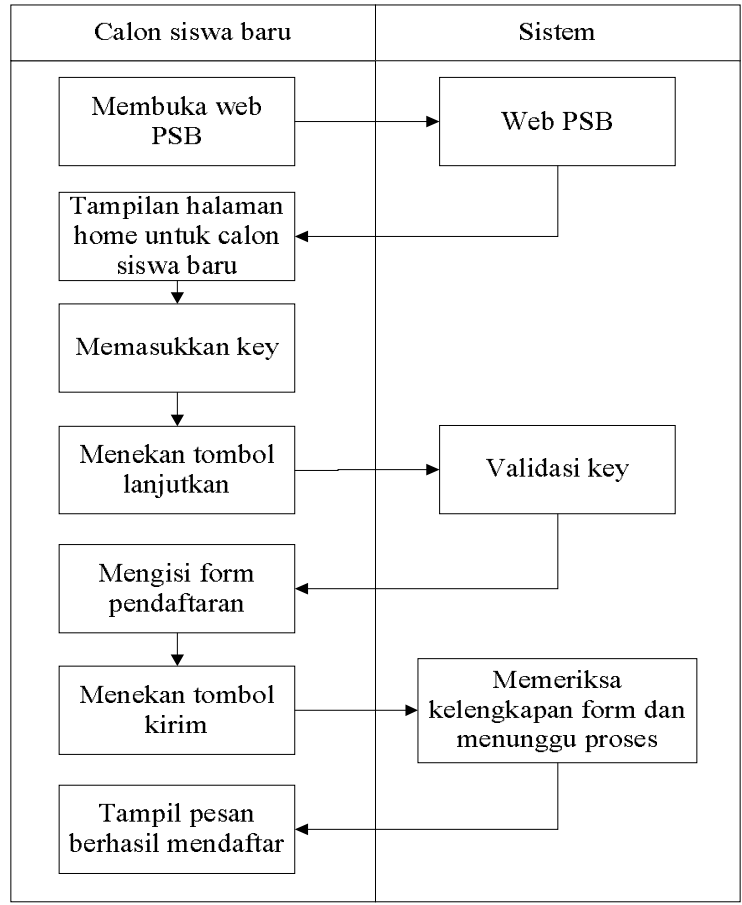

Gambar 4. Flowchart Alur Kerja Sistem untuk Peserta PSB 


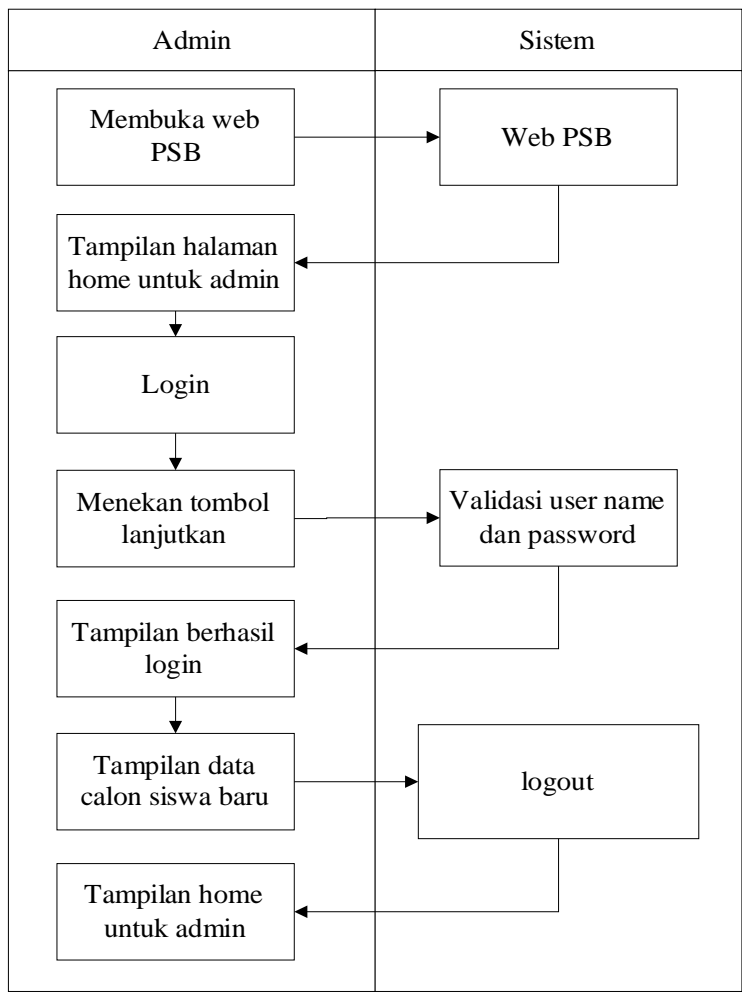

Gambar 5. Flowchart Alur Kerja Sistem untuk Admin PSB

\subsection{Implementasi}

Tampilan Halaman Depan merupakan halaman utama dari perancangan website dan memberikan sebuah informasi kepada calon siswa. Tampilan menu utama dapat dilihat pada gambar 5.

\section{Halaman Menu Utama}

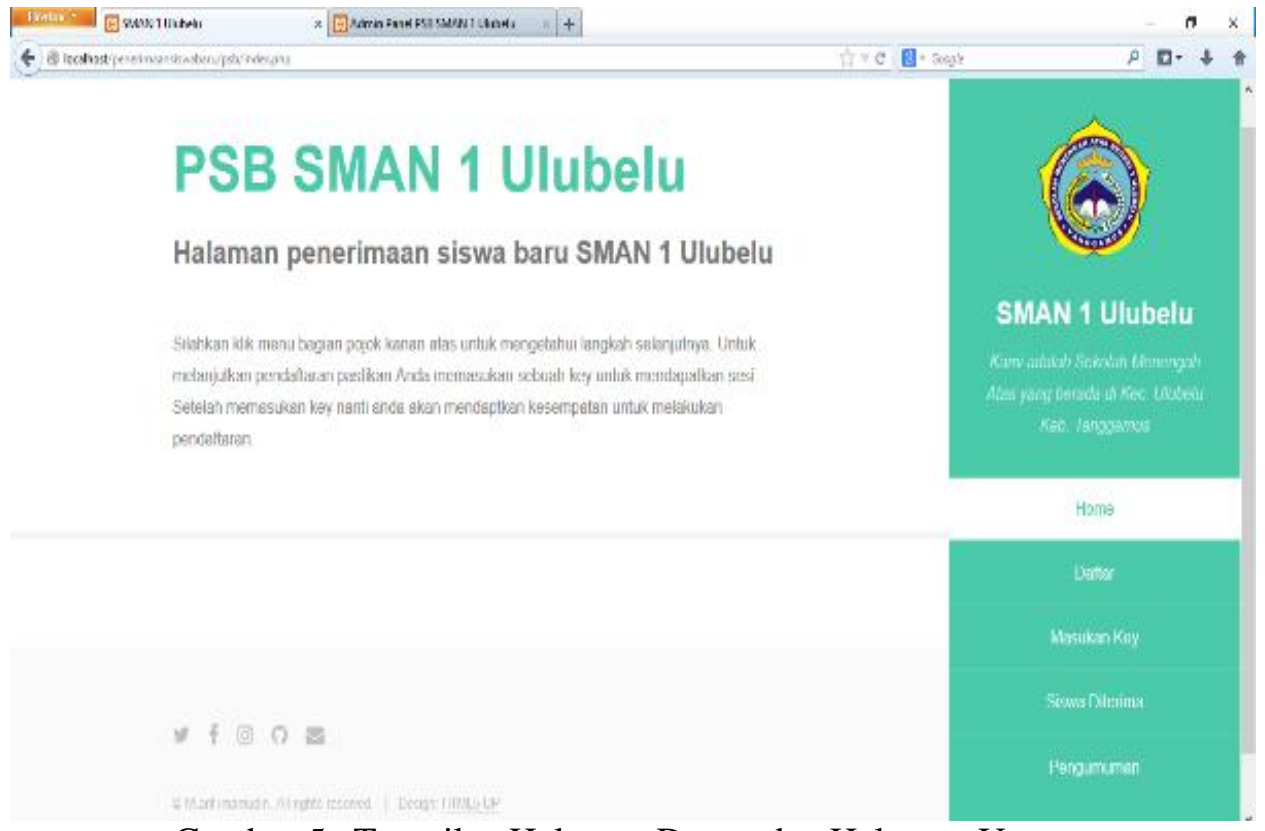

Gambar 5. Tampilan Halaman Depan dan Halaman Utama 


\section{Halaman Masukkan Key}

Dihalaman ini berisi menu memasukkan key untuk proses pendaftaran oleh calon siswa baru. implementasi dapat dilihat pada tmpilan gambar 6 .

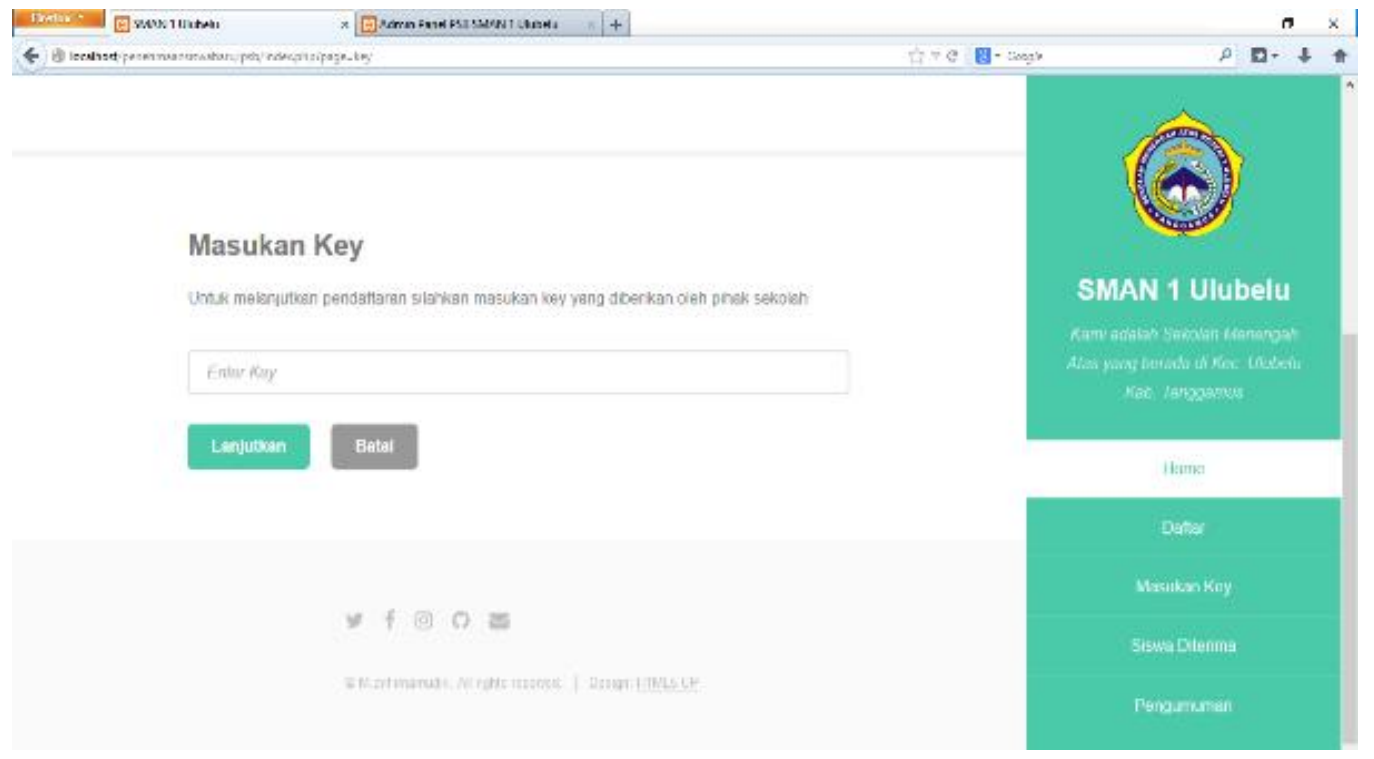

Gambar 6. Halaman Masukkan Key

Tampilan Halaman Pendaftaran Siswa

Tampilan Pendaftaran Siswa berisi form untuk mengisi data calon siswa baru. Implementasi rancangan form pendaftaran dapat dilihat pada gambar 7 .

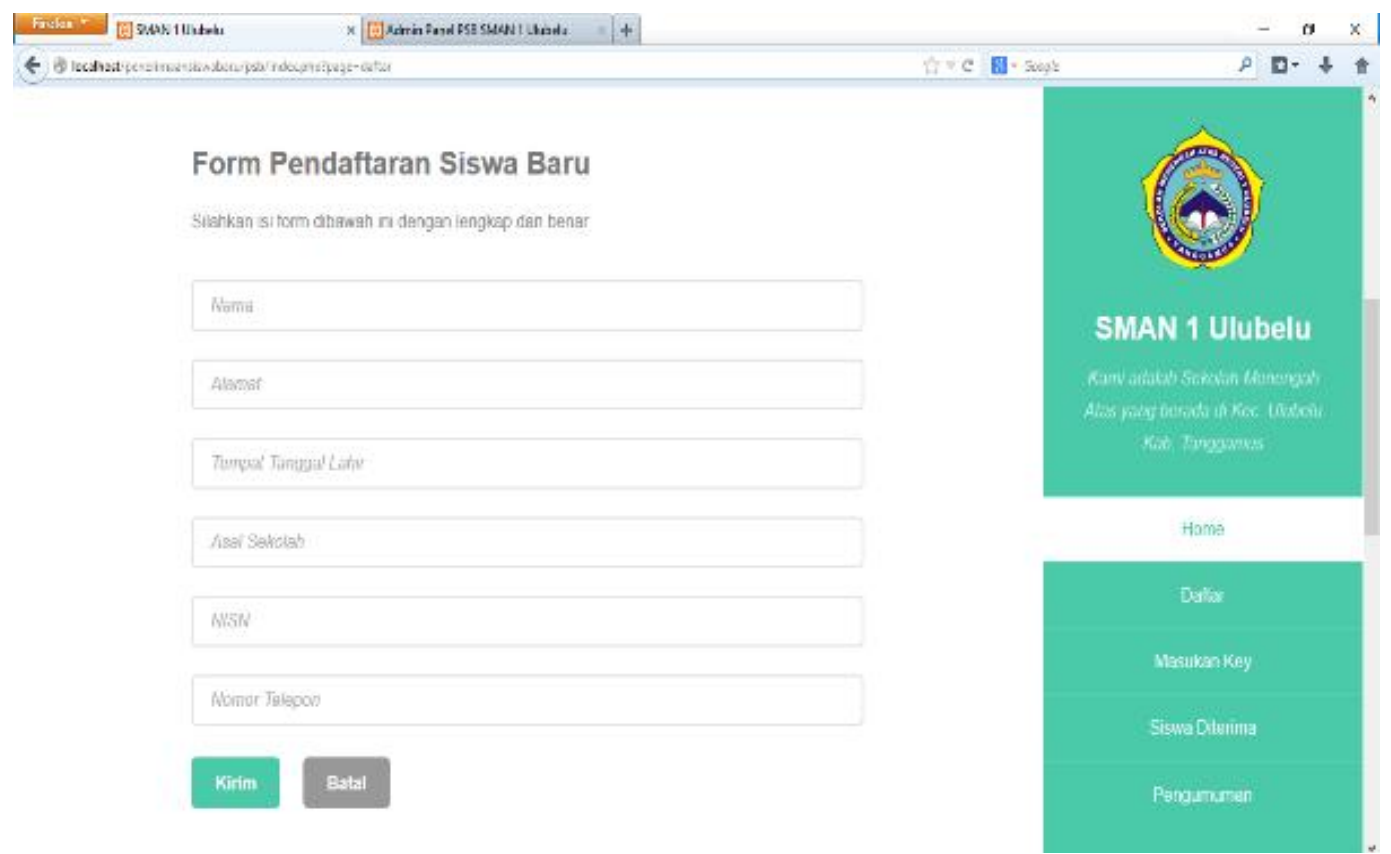

Gambar 7. Tampilan Form Pendaftaran Siswa

Tampilan Halaman Pengumuman

Tampilan pengumuman berisi tentang pengumuman setelah melakukan pendaftaran. Implementasi program dapat dilihat pada gambar 8. 


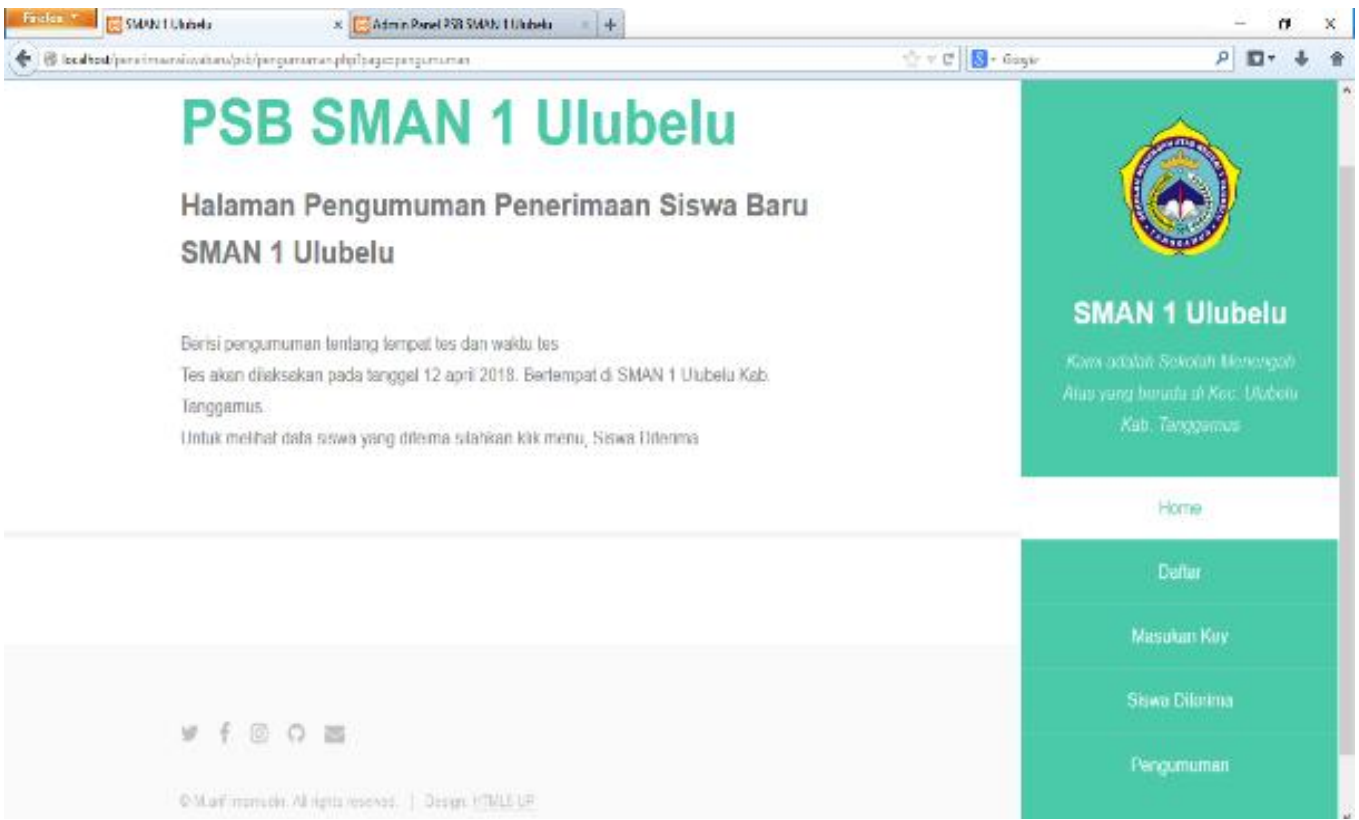

\section{Gambar 8. Tampilan Halaman Pengumuman}

Tampilan Halaman Siswa Diterima

Tampilan halaman ini berisi data siswa yang di terima di SMAN 1 Ulu Belu. Implementasi program dapat dilihat pada gambar 9.

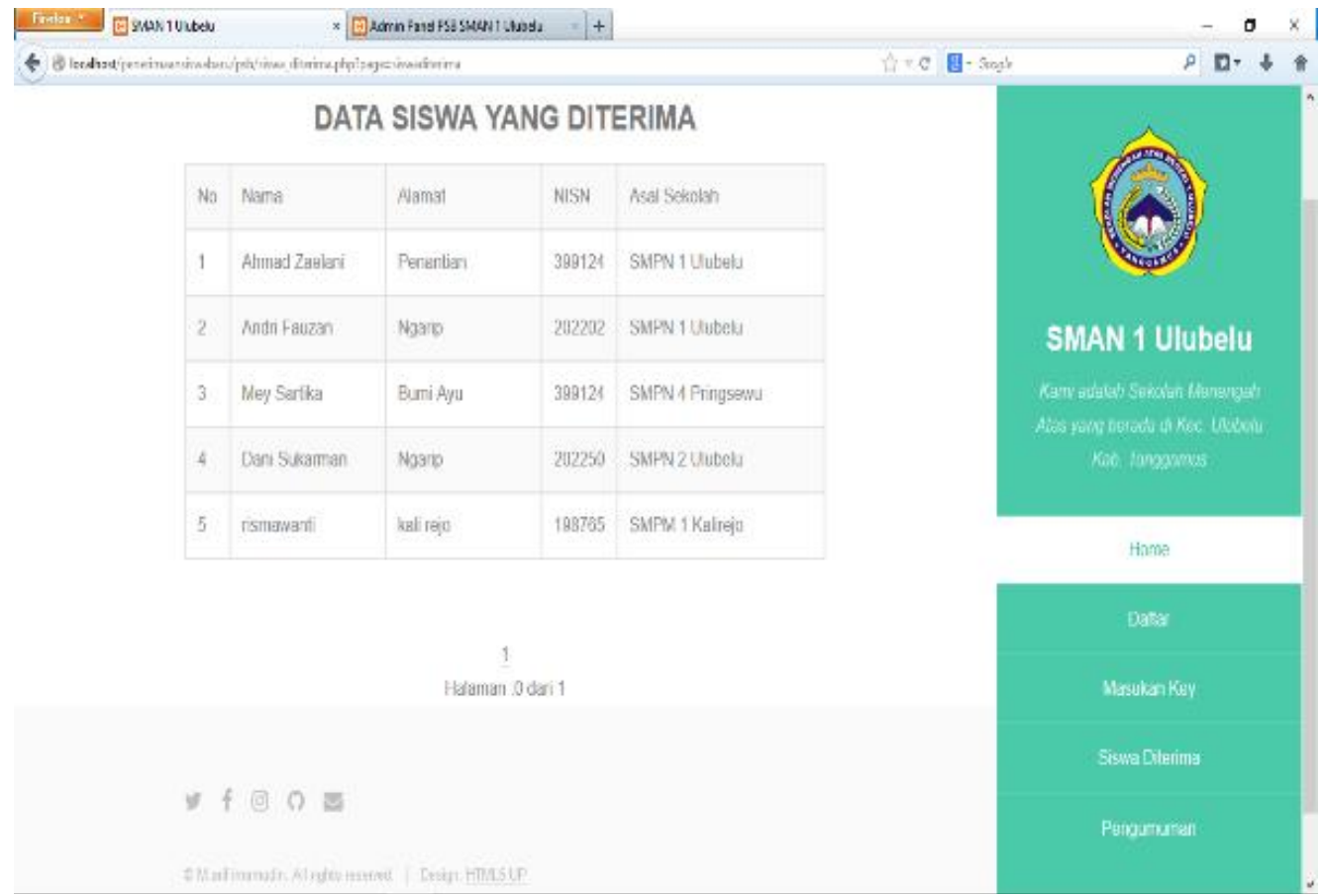

Gambar 9. Tampilan Halaman Siswa Diterima

Tampilan Halaman Login Admin

Tampilan halaman ini merupakan proses login admin untuk melihat data siswa yang sudah mendaftar. Implementasi program dapat dilihat pada gambar 10. 


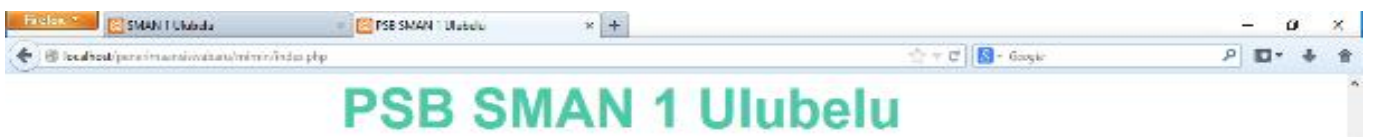

Halaman Admin Panel penerimaan siswa baru

SMAN 1 Ulubelu

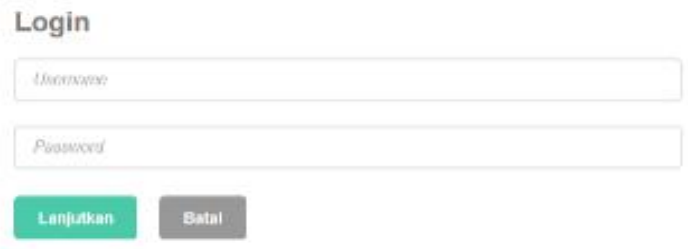

Gambar 10. Tampilan Halaman Login Admin

Tampilan Halaman Data Calon Siswa

Halaman ini berisi data calon siswa baru yang sudah melakukan pendaftaran. Implementasi program dapat dilihat pada gambar 11.

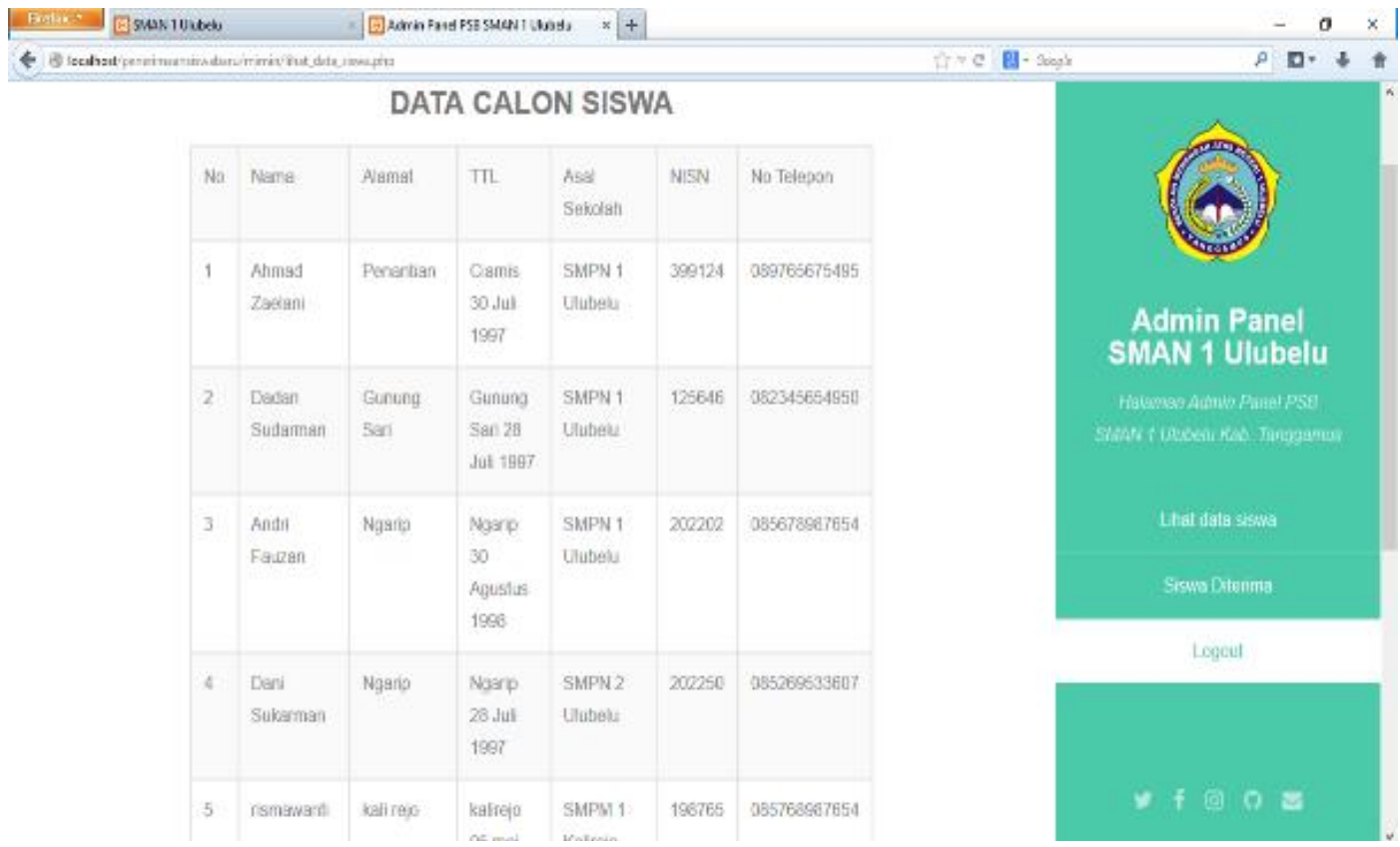

Gambar 11. Tampilan Halaman Data Calon Siswa

\subsection{Analisa Hasil Penelitian}

Dari seluruh penelitian dan hasil implementasi yang telah dilakukan, hasil penelitian tersebut dapat dijelaskan sebagai berikut:

1. Adanya sistem website yang dimaksudkan program ini dapat melakukan proses akses internet untuk masuk kehalaman website aplikasi yang bisa diakses di smartfon.

2. Dengan adanya web ini dapat mempermudah calon siswa dalam melakukan proses pendaftaran di SMAN 1 Ulu Belu 
3. Menu login program ini melakukan proses login untuk masuk ke halaman utama sesuai dengan hak akses admin.

4. Menu masukkan key program ini melakukan proses login untuk masuk ke halaman pendaftaran calon siswa sesuai dengan hak akses user.

5. Database program menampilkan hasil inputan yang dimasukan kedalam data yang nantinya akan diproses atau diletakkan pada pendataan.

6. Halaman menu didalam halaman tersebut nantinya akan diuji apakah menu-menu yang ada di program aplikasi web tersebut dapat berjalan dengan baik atau sebaliknya. Jika program aplikasi dapat dijalankan sesuai dengan apa yang diinginkan dari awal maka artinya pengujian dan hasil analisa yang dilakukan oleh penulis berhasil.

7. Menu logout program ini melakukan proses logout atau keluaran dari aplikasi.

\subsection{Hasil Uji Sistem}

Peneliti juga melakukan analisis implementasi aplikasi dengan memberikan quisioner berisi beberapa pertanyaan yang diberikan kepada 35 orang reponden Guru dan Wali Murid tentang webite penerimaan siswa baru berbasis web mobil yang telah dibuat. Dari 35 orang yang mengisi quisioner dan melakukan uji website yang telah dibuat didapatkan sebanyak $80 \%$ orang menjawab merasa puas dengan website penerimaan siswa baru yang telah dibuat. Sedangkan $20 \%$ lagi menjawab kurang puas dengan website penerimaan siswa baru berbasis web mobile dikarenakan keterbatasan jaringan di tempat asal responden.

\section{KESIMPULAN}

Berdasarkan analisis, perancangan yang telah dilakukan dalam pembuatan sistem informasi penerimaan siswa baru berbasis web mobile di SMAN 01 Ulu Belu, maka dapat diambil kesimpulan sistem informasi penerimaan siswa baru berbasis web mobile dari hasil penelitian ini dapat memberi kemudahan akses informasi dan proses pendaftaran bagi calon siswa. Sistem informasi penerimaan siswa baru berbasis web mobile ini juga dapat mengatasi pengolahan data calon siswa menjadi lebih baik karena disimpan dalam suatu basis data yang terintegrasi.

\section{SARAN}

Berdasarkan pembahasan diatas mengenai implementasi web penerimaan siswa baru masih berbasis web mobile. Diharapkan penelitian selanjutnya dapat mengembangkan dengan aplikasi berbasis android ataupun dengan metode lainnya demi kesempurnaan penelitian ini.

\section{UCAPAN TERIMA KASIH}

Penulis mengucapkan terima kasih kepada Ketua Yayasan Pendidikan Startecht, Ketua STMIK Pringsewu yang telah memberi dukungan finansial terhadap penelitian ini. Serta Kepala SMAN 1 Ulubelu yang telah mengizinkan penelitian dan uji sistem di Sekolah

\section{DAFTAR PUSTAKA}

[1] B. P. S. K. Tanggamus, 2017. "Data Sekolah dan Siswa yang Ada di Kabupaten Tanggamus Menurut Badan Statistik Tanggamus". 
[2] S. Santoso, D. Saputra, and D. Pebriana, 2013. "Aplikasi Penerimaan Siswa Baru Berbasis Mobile Web Studi Kasus: SMA Citra Islami,” SESINDO, pp. 2-4.

[3] N. H. Cahyana, E. Y. Prasetyo, and H. Himawan, 2015. "Aplikasi Penerimaan Siswa Baru Berbasisweb (SMK Negeri 3 Yogyakarta)," upnyk, pp. 1-8.

[4] S. Hartati, A. Ikwan, and R. A. Pradana, 2018. "Pengembangan Sistem Aplikasi SMS Gateway Sebagai Media Penyampaian Data Kehadiaran Siswa pada Orang Tua," Jatisi, Vol. 4, No. 2, pp. 187-193..

[5] M. Abdurahman, 2016. "Sistem Informasi Jadwal Perkuliahan Berbasis Web Mobile pada Politeknik Sains dan Teknologi Wiratama Maluku Utara," Indones. J. Netw. Secur., Vol. 5, No. 2, pp. 49-56.

[6] N. Azizah and Y. Ramadhani, 2011. "Pembangunan Sistem Informasi Penerimaan Siswa Baru di Sekolah Menengah Kejuruan Al-Irsyad Tegal," Sentra Penelit. Eng. dan Edukasi, vol. 3, no. 3, pp. 131-139.

[7] M. Muslihudin, 2013. "Sistem Informasi Penjualan Batik Basurek Berbasis Web pada Basurek Collection Bengkulu," J. TAM ( Technol. Accept. Model ), Vol. 1, No. 1, pp. 59.

[8] S. Hartati, N. Ayu Kristiana Dewi, D. Puastuti, M. Muslihudin, and N. Setio Budi, 2017. "Sistem Aplikasi Educhat Stmik Pringsewu Berbasis Android Sebagai Media Komunikasi dan Informasi," J. Teknosi UNAND, Vol. 03, No. 01, pp. 143-152.

[9] Jeperson Hutahaean, 2014. "Konsep Sistem Informasi,” Vol. 53, No. 9. Deepublish.

[10] A. Ridha and S. R. Rusydi, 2016. "Pengaruh Lingkungan Keluarga dan Sekolah Terhadap Perilaku Siswa," Tarbawi, Vol. 1, No. 1, pp. 52-58,

[11] J. Vamela, H. Adelina, and Y. Nurmalisa, 2012. "Persepsi Siswa Tentang Proses Pembelajaran oleh Guru Non PKn di SMA Bina Mulya Kedaton Bandar Lampung," J. Penelit. Pendidik.

[12] Y. Utama, 2011. "Sistem Informasi Berbasis Web Jurusan Sistem Informasi Fakultas Ilmu Komputer Universitas Sriwijaya,” J. Sist. Inf., Vol. 3, No. 2, pp. 359-370.

[13] U. Yadi, "Sistem Pendukung Keputusan Untuk Menentukan Prioritas Penanganan Perbaikan Jalan Menggunakan Metode Saw Berbasis Mobile Web," J. Sist. Inf., vol. 5, no. 1, pp. 566-579, 2013.

[14] R. Hermawan, A. Hidayat, and V. G. Utomo, "Sistem Informasi Penjadwalan Kegiatan Belajar Mengajar Berbasis Web (Studi Kasus: Yayasan Ganesha Operation Semarang)," J. Evolusi, Vol. 3, No. 2, pp. 1-8, 2015.

[15] Y. J. Syafitri, "Perancangan Sistem Informasi Pemesanan Obat Menggunakan Bahasa Pemrograman Berorientasi Objek," KomTekInfo, vol. 4, no. 1, pp. 21-28, 2013.

[16] O. Muhammad Muslihudin, 2016. "Analisis dan Perancangan Sistem Informasi Menggunakan Model Terstruktur dan UML. Andi Offset, Yogyakarta". 